\title{
Beyond the Liberal Democracy Paradigm: A Fresh Look at Power and Institutions
}

\author{
Goran Hyden
}

\begin{abstract}
Compared to political developments in Eastern Europe and Latin America, democratization in sub-Saharan Africa has been more problematic and uneven. Looking at the performance in four subregions-central Africa, East Africa, southern Africa, and West Africa-yields no convincing evidence of a "wave" of democratization; countries next to each other differ considerably with regard to their Freedom House scores. This does not mean that democratization has necessarily stalled, but it does demonstrate that the prevailing vertical cleavages along ethnic, racial, or religious lines can make such a transition volatile, as suggested by the cases of Burundi, Mali, and even Kenya. While political competition in mature democracies, typically divided along horizontal group or class lines, tends to generate positive-sum outcomes, such competition in Africa easily turns into "prisoner's dilemma" games. The uncertainty about the value of cooperation in such situations usually produces political "truces" that are easily abandoned if the costs of adherence exceed the benefits. Against the background of this prevailing political logic, this article calls for a new approach to conceptualizing notions of "institution" and "power" in the analysis of politics in the region.
\end{abstract}

African Studies Review, Volume 59, Number 3 (December 2016), pp. 169-180

Goran Hyden is a distinguished professor emeritus of political science at the University of Florida who has written extensively on politics and development in Africa. His publications include Beyond Ujamaa in Tanzania (University of California, 1980), No Shortcuts to Progress (University of California, 1983), Governance and Politics in Africa, co-edited with Michael Bratton (Lynne Rienner, 1992), Making Sense of Governance, co-authored with Julius Court and Kenneth Mease (Lynne Rienner, 2004), and African Politics in Comparative Perspective (Cambridge, 2006; 2nd revised edition, 2013). He has also published in journals devoted to comparative and African politics. He served on the board of the African Studies Association (1991-96) and was its president in 1995. In 2015 he was awarded the ASA's Distinguished Africanist Award. E-mail: ghyden@ufl.edu 
Résumé: Par rapport à l'évolution politique en Europe de l'est et en Amérique latine, démocratisation en Afrique subsaharienne a été plus problématique et inégale. L'examen des performances de quatre sous-régions-Afrique centrale, Afrique de l'est, Afrique australe et Afrique de l'Ouest—ne donne aucune preuve convaincante d'une "vague" à la démocratisation; les pays proches des uns et des autres diffèrent considérablement en ce qui concerne leurs scores de "Freedom House." Cela ne signifie pas que la démocratisation a nécessairement calé, mais cela démontre que les clivages verticaux qui sont prévalant le long des lignes ethniques, raciales ou religieuses peuvent faire une telle transition instable, comme l'a suggéré les cas du Burundi, Mali et du Kenya. Alors que la compétition politique dans les démocraties matures, généralement divisée le long de groupe horizontal ou lignes de classe, a tendance à générer des résultats positifs, cette concurrence en Afrique se transforme facilement en un jeu appelé "dilemme du prisonnier." L'incertitude quant à la valeur de la coopération dans de telles situations produit généralement des "trêves" politiques qui sont facilement abandonnées si les coûts d'adhésion dépassent les bénéfices. Dans le contexte de cette logique politique qui prévaut, cet article appelle une nouvelle approche de conceptualisation des notions d' "établissement" et de "pouvoir" dans l'analyse politique de la région.

Keywords: Democratization; governance; institutions; power; development

\section{Introduction}

Joel Barkan believed in liberal democracy, but he was also a realist who recognized that power is important and that institutions take time to develop. He took pride in seeing African legislatures making forward strides while at the same time he understood that the underlying structures of society gave these institutions a particular character. This article in memory of Joel Barkan's scholarship reflects this dual interest of his.

Since the end of the Cold War, liberal theorists have stressed that international peace and individual rights are best advanced through cosmopolitan frameworks whereby democratic and peaceful states take a leading responsibility for ensuring the interests of common humanity. This thesis was confirmed in the report of the 2001 International Commission on Intervention and State Sovereignty. The tutelary role of more advanced democracies has put them at the forefront of democratization around the world. Their effort has been generously funded and supported by both governments and nongovernmental organizations in the North.

The liberal-democratic thesis has been subsumed under such mantras as "good" or "democratic" governance and has dominated the global political agenda since the early 1990s. It rests on two basic premises: (1) that democracy should become "the only game in town," and (2) that democratic governance is a prerequisite for accelerating national development. Political scientists have bought into the relevance of this agenda, and in sharp contrast to the earlier period of comparative politics research, which centered 
on the state and its relation to society, more recent scholarship has focused on issues of regime transition and democratic consolidation. Crawford Young's seminal work The African Colonial State in Comparative Perspective (1994) summed up the main achievements of this period with specific reference to Africa. By this time the so-called Third Wave of democratization (Huntington 1991) was already in full force and interest had moved on to examining how institutions might shift political behavior and choice in a liberal democratic direction.

A quarter-century later, the time has come to look at how far the liberal-democratic thesis or paradigm (i.e., the "only game in town") has been realized in the African context. This article will do so by first examining how far liberal-democratic forms of governance have been institutionalized and then by discussing the effects of different levels of democratic achievement on national development. A third section tries to explain the challenges facing democratization in Africa, and the article ends with a discussion of the implications of these challenges for the study of African politics.

\section{The Only Game in Town?}

The universal claim of the liberal-democratic thesis means that it has usually been pursued with little concern for how it fits prevailing countryspecific social and economic realities. Not surprisingly, therefore, the democratization record varies. It has been positive in countries that were already industrialized and are part of the European heartland or culturally adjacent to it through emigration (e.g., Latin America). There has been less evidence of success in countries that are nonindustrial or in an incipient stage of modernization. This is especially true for sub-Saharan Africa, where the legacy of colonial rule tends to reinforce a skeptical, if not suspicious, posture toward interventions driven by a Western political agenda. In 2014 sub-Saharan Africa, along with the Middle East and North Africa, had the lowest scores on the Freedom House index of political and civil liberties (Freedom House 2015). The Third Wave of democratization has hit Africa unevenly. Unlike Eastern Europe and Latin America, where it swept whole regions and the democratic ideals spread from one country to another, there has been much less evidence of such dissemination across Africa or across the more homogenous subregions.

Sub-Saharan Africa is politically divided into four subregions: West Africa, central Africa, East Africa, and southern Africa. Each has its own institutional mechanisms for pursuing integration, peace, and prosperity: the Economic Community of West African States (ECOWAS) for West Africa, the Economic Community of Central African States (ECCAS) for central Africa, the East African Community (EAC) for East Africa, and the Southern African Development Community (SADC) for southern Africa. Although all countries come together in the African Union, member countries of each subregion tend to have the closest interaction and therefore the greatest chance of 
influencing one another. So, how has democratization progressed in these subregions over the past twenty-five years?

According to the Freedom House ratings, in 2014 four-fifths of the African countries remained either "non-free" (20) or "partially free" (19); only eight countries-one out of six-were listed as "free" (Freedom House 2014). It is clear that some progress has been made but also that the move toward liberal democracy has been less impressive and consistent since 2000, prompting The Economist (2012), for instance, to state that the democratic transition in Africa had stalled. A breakdown of the trend by subregion and the average score for all countries in each subregion are shown in table 1 below.

The Freedom House considers countries scoring below 2.5 as "free," while those that score between 3.0 and 4.5 are considered "partly free." Those with a score of 5.0-7.0 are listed as "non-free." There are differences among the subregions, with southern and West Africa faring generally better and central Africa showing the worst performance. The table also shows a slowing down of the transition process after 2000, but it is not uniform across sub-Saharan Africa. While central Africa and East Africa confirm the loss of momentum toward democracy and southern Africa treads water, West Africa has indeed demonstrated continuous progress, albeit incrementally and still within the "partly free" range.

Star performers - that is, countries that are rated as "free"-are few and unevenly distributed across the region. Southern Africa has four-Botswana, Mauritius, Namibia, and South Africa; West Africa also has four-Benin, Cape Verde, Ghana, and Senegal-while central Africa and East Africa have none. The influence that these strong performers have on their neighbors seems to be limited. Democratic reforms tend not to spread from one country to another but to be driven by domestic political dynamics. With the exception of southern Africa, where there is a core of democratic countries, democratic states in the rest of Africa tend to be surrounded by authoritarian regimes.

Table 1. Democratic Transition by Subregion, 1990-2014

\begin{tabular}{llll}
\hline Region/Year & $\mathbf{1 9 9 0 - 9 1}$ & $\mathbf{2 0 0 0 - 1}$ & $\mathbf{2 0 1 4}$ \\
\hline West Africa* & 5.3 & 4.2 & 3.8 \\
Central Africa** & 5.7 & 5.3 & 6.0 \\
Eastern Africa*** & 4.2 & 4.6 & 4.2 \\
Southern Africa**** & 4.6 & 3.5 & 3.5
\end{tabular}

* Countries include Benin, Burkina Faso, Cape Verde, Côte d'Ivoire, Equatorial Guinea, The Gambia, Ghana, Guinea, Guinea-Bissau, Liberia, Mali, Mauritania, Niger, Nigeria, Sao Tomé and Principe, Senegal, and Togo.

** Countries include Cameroon, Central African Republic, Chad, Republic of Congo, Democratic Republic of Congo, and Gabon.

*** Countries include Burundi, Djibouti, Eritrea, Ethiopia, Kenya, Rwanda, Seychelles, Somalia, South Sudan, Sudan, Tanzania, and Uganda.

**** Countries include Angola, Botswana, Lesotho, Madagascar, Mauritius, Mozambique, Namibia, South Africa, Swaziland, Zambia, and Zimbabwe. 
There are also pockets, such as the whole of central Africa, where only authoritarian regimes persist. It is no surprise, therefore, that the institutional mechanisms at the subregional level tend to be ineffective as drivers of reform. SADC has been unsuccessful in promoting regime change in President Mugabe's autocratic Zimbabwe. The EAC could not prevent President Nkurunziza of Burundi from stage-managing a constitutional amendment that allowed him to run for a third term as head of state in 2015. Even ECOWAS, which seems to have been the most active of the subregional institutions, has not been as successful in driving political reform as it has in securing peace in conflict-ridden countries like Liberia and Sierra Leone.

At the continental level, countries in sub-Saharan Africa tend to join those in North Africa in insisting on the rights of sovereign states to resist initiatives from the outside to force political change in a liberal-democratic direction. The most striking case has been the effort by the African Union to oppose the drive by the International Criminal Court (ICC) to punish African leaders who act with impunity. This more than any other incident has shown that civil and political liberties in Africa rest on a fragile ground. Using Afrobarometer data, Bratton (2010) has shown that the "D" word is still anchored only among educated urbanites. The "supply" of democracy in the form of generous financial support by Western donors has often exceeded the demand for it, and the full potential of democracy-including the promise of accountable governance-has yet to be fulfilled (Bratton \& Logan 2006). Informal institutions fed by an "economy of affection"-i.e., communal forms of cooperation (Hyden 1980) — still exercise influence on political behavior and choice, as confirmed by the high levels of perceived corruption documented by Transparency International (2015). Africans may believe in elections as the right way to select their leaders, but they are unable to take full advantage of the opportunities that the liberal form of representative democracy offers. As O'Donnell (1994) argued with reference to Latin America, regime transition tends to end with a strong executive that is difficult to challenge.

The formal institutions of liberal democracy, therefore, tend to be the only "frame in town" across most of Africa today, but it is not yet the only "game in town" if that idea suggests that political actors adhere to the prescribed rules of the system.

\section{The Governance-Development Link}

A good deal of research in the 1990s was devoted to demonstrating that democracy is good for economic growth. The debate around this issue was eventually settled by Przeworski (2000) in a global review of the relationship between regime type and economic development in which he found no persuasively positive outcome. While there was no reason, as the author argued, to sacrifice democracy at the altar of development, the study showed that political regimes do not affect the rate of investment or the growth of total income. 
This debate has not reoccurred in recent years despite the fact that the international donor community has continued to insist that democracy is best for development. There is reason, therefore, to once more examine to what extent this thesis holds water. The first issue that needs to be resolved is the definition of development. Most economists and political scientists have for a long time used economic growth as a measure of development. But with the growing acceptance in the policy and academic community of the Human Development Index issued annually by the United Nations Development Programme (UNDP), there has also been a tendency to accept the standards of this more broad-based index (which combines economic and social indicators such as life expectancy at birth, mean years of schooling, expected years of schooling, and gross national income per capita) to produce a country development score. Table 2 shows how the HDI scores have changed across the subregions between 1990 and 2013 (a higher score means a higher level of human development).

In a global perspective, these are low scores (see table 3). The top ten countries in the world all score above 0.9 with Norway, Australia, and Switzerland sitting at the peak of the global rankings in 2013. They are all classified as enjoying "very high" human development. The Africa Region has only two countries-Mauritius and Seychelles — in the "high" category, with the rest of them falling into the "medium" or "low" categories. As with the Freedom House Index, African countries tend to perform poorly. To be sure, there has been progress, including in the two subregions-central Africa and East Africa-that scored lowest on the FDI. Even so, the majority of the countries rest at the bottom of the table.

It is tempting, therefore, to conclude that the low HDI scores are the result of low scores on the FDI; human development is low because democratic governance is absent or weak. A closer look at individual country performances, however, suggests that countries with poor FDI scores were among the best human development performers between 1990 and 2013, while only one country classified as "free"-Benin-was among the top ten human development performers. With increased violence in both Mali and Niger, it is doubtful that their development performance is sustainable. The two top countries, therefore, are Rwanda and Ethiopia-countries that have pursued modernization by drawing on institutional legacies derived from their monarchical pasts. Their top standing has also been confirmed in other contexts. For example, both of them were rated as best African

Table 2. Changes in Human Development Scores by Subregion, 1990-2013

\begin{tabular}{llll}
\hline Region/Year & $\mathbf{1 9 9 0}$ & $\mathbf{2 0 0 0}$ & $\mathbf{2 0 1 3}$ \\
\hline West Africa & 3.50 & 4.07 & 4.63 \\
Central Africa & 3.74 & 4.11 & 4.66 \\
East Africa & 3.39 & 4.22 & 4.95 \\
Southern Africa & 4.79 & 4.60 & 5.37 \\
\hline
\end{tabular}


Table 3. Comparison of 2014 FDI Scores with Ten Best Human Development Performers, 1990-2013

\begin{tabular}{lll}
\hline Country & FDI Score 2014 & $\begin{array}{l}\text { Percentage of HDI Improvement } \\
\mathbf{1 9 9 0 - 2 0 1 3}\end{array}$ \\
\hline Rwanda & 6.0 & $52 \%$ \\
Mali & 4.5 & $43 \%$ \\
Niger & 3.5 & $37 \%$ \\
Ethiopia & 6.0 & $34 \%$ \\
Uganda & 5.5 & $34 \%$ \\
Gambia & 6.0 & $32 \%$ \\
Malawi & 3.5 & $31.5 \%$ \\
Sudan & 7.0 & $30 \%$ \\
Benin & 2.0 & $28 \%$ \\
Tanzania & 3.0 & $28 \%$ \\
\end{tabular}

performers in terms of progress toward the Millennium Development Goals (United Nations 2014).

It remains to explain why African countries score low on both these indices and why countries with a poor democratic performance tend to be better development performers.

\section{Africa's Particular Political Logic}

In order to fully appreciate the African predicament when it comes to democratization, it is necessary to add a historical perspective on how the liberal-democratic model became rooted elsewhere. In Western societies it is the product of centuries of philosophical discourse and debate within a particular cultural and intellectual tradition. It is an abstraction that is broadly accepted and serves as the moral foundation for how liberal democratic societies operate. It assumes a society divided into groups of people who are ready to agree to disagree but do so in a reasonable manner within an institutional framework that stands above these disagreements. Justice is procedural, not substantive. Adherence to the rules of the game rather than the outcome is what matters. When disagreements cannot be resolved there are institutional "third-party" mechanisms for resolving them. Fairness is assessed with respect to process ("due process") and reasonable argument. As Barry (1995) argues, the liberal-democratic model depends on a notion of justice as impartiality. This concept of justice is inconsistent with any claims to special privilege based on grounds that cannot be freely acceptable to others. It rules out claims to advantage based, for example, on ethnicity or race, which are so nakedly self-serving that others in society cannot seriously be asked to accept them.

Because liberal democracy accepts that partiality of interests and viewpoints is inevitable, there is always need for arbitration. The underlying assumption is that there is no consensus on the nature of the public good. 
Each actor realizes that he cannot achieve things without the help of others. In order to obtain their cooperation, he must act fairly. People motivated by fairness reinforce one another's motives. The logic of liberal democracy, therefore, tends to produce an "assurance game," a form of politics based on trust. Through compromise and respect for the rules, governance tends to generate lasting public good in the form of policies that apply equally to every segment of society.

Lipset and Rokkan (1967) showed how in the late nineteenth and early twentieth centuries the expansion of a capitalist economy in Europe and North America, in combination with industrialization, shaped the political landscape as these societies also opened their doors to liberal democracy. Collier and Collier (1991) carried out a similar study of how the working class in Latin American countries was integrated into national governance structures in different ways depending on who was in power. Both volumes highlight how the middle class realized that it could not afford to ignore the interests of the workers, and vice versa. An assurance game evolved and became institutionalized.

African countries not only lack the long intellectual tradition that produced a liberal democracy in the West, but are also without the socioeconomic structures that helped institutionalize the model in Europe and the Americas. Because these countries have yet to modernize and to produce a middle class that is strong enough to create lasting bonds across ethnic and religious boundaries, society tends to be divided primarily along vertical lines. Some of these divisions follow ethnic or religious lines, but even party systems display this pattern. Political parties are not based on a definite common economic interest but tend to represent a conglomerate of identity-based groups that work together in the hope of getting a share of whatever benefits politics is capable of producing. The logic of African politics is driven by a notion of justice that centers on achieving an outcome that is mutually advantageous to actors involved. It is justice as reciprocity. This logic produces a dynamic whereby political accords are agreed upon because the costs of violating them are higher than the costs of complying.

Such agreements, however, rarely lead to lasting social or political contracts. They are more like truces-they keep the rival factions from engaging in devastating conflicts but they do not lay the foundation for a sustainable transition to liberal democracy. A political system based on justice as mutual advantage is inherently unstable because, as Barry (1995) also argues, it has the structure of a prisoner's dilemma- a condition in which the value of cooperation with others is uncertain. It does not prevent one party to the conflict from defecting while all others adhere to the accord. This situation is plentifully evident in African countries. Disillusioned politicians jump from one party to another; political alliances-as, for instance, in Kenya, Malawi, and Zambia—keep shifting; and agreements made between political actors are often abandoned in favor of more rewarding or politically necessary options. Where the costs of defection are insignificant, such defection is easy. For example, where the balance of power is relatively even, no 
party has the capacity to control the other and defection may occur on both sides-in the worst case scenario leading to violent conflict. The situation in South Sudan illustrates such a scenario, as does the political deadlock after the 2015 elections in Zanzibar.

Because a balanced situation of justice as mutual advantage is difficult to sustain, a "strong man" usually ends up serving as the ultimate arbiter. Rwanda is a case in which this has played out since the genocide against the Tutsis in 1994. With President Kagame at the helm, the government has applied political sanctions against those who do not agree with his strongarm approach, one that has produced significant dividends in terms of development, including poverty reduction, but has led liberal critics to cry "foul" over its governance record (Reyntjens 2013).

\section{Implications for the Study of African Politics}

A quarter-century after the study of democratization began in earnest in comparative politics and African studies, there are two lessons that seem especially pertinent as we look beyond the dominant focus on democratic transition and regime change.

The first is the need to "dig deeper" to incorporate concerns about power. The political settlement approach that has emerged in recent years as a preferred mode of studying political economy provides an avenue for doing so. A political settlement is defined as a "combination of power and institutions that is mutually compatible and also sustainable in terms of economic and political viability" (Khan 2010:4). Its starting point is the classification of societies on the basis of their dominant institutions and the underlying distributions of power. The concept of power in this political settlements framework is defined as "holding power"- the process through which individuals and groups are able to assert or maintain claims to ownership of property and income flows. Power is exercised through violence or the threat of violence, ideas, sociological and institutional hierarchies, and traditional authority as well as through access to economic resources. An understanding of the distribution of power in society comes from the analysis of historical struggles over resource flows. Power, therefore, exists in institutional forms such as positions within the state or within political parties, but it also exists outside formal institutions. Much like Gramsci's conceptualizations, this framework sees the ability to organize politicallyfor example, to mobilize people to resist changes by setting up a demonstration or organizing a strike-as critical to the prospects for social transformation (Gray \& Whitfield 2014).

The problem with the political settlement approach as developed by Khan and discussed by Gray and Whitfield is that it assumes "historical struggles" over resources-that is, the presence of social forces that can transform society through political domination. But such forces are hardly present anywhere in Africa, with the possible exception of South Africa. Instead, politics keeps being dominated by personal_-neopatrimonial"—rulers 
(Medard 1982; Erdmann \& Engel 2007). This concept has been criticized for being overused and not really capable of explaining differential policy outcomes (Therkildsen 2005; Pitcher at al. 2009; Mkandsluawire 2013: Gray \& Whitfield 2014). Neopatrimonialism, however, is not necessarily only an independent variable; it is also a dependent variable in the context of how political settlements are reached in Africa's identity-driven polities.

When there is no external enemy against which political leaders can mobilize support and earn legitimacy, political settlements in African countries tend to be driven by realist rather than idealist considerations (Henderson 2015). It is outcome rather than procedure that matters. If defecting from an accord has few costs, it is likely to occur. If excessive power is necessary to achieve a particular outcome, it tends to be applied. Wherever political settlements rest on mutual advantages and function as truces rather than lasting agreements, there is an obvious need for someone with personal authority to hold them in check. The persistent presence of "Big Men" or neopatrimonial rulers in contemporary Africa reflects the realist but often precarious nature of its political settlements. Personal rule is a structural component of governance in Africa. It is necessary to manage political settlements, whether the method is moral authority, patronage, or coercion. The neopatrimonial ruler acts as the ultimate arbiter by changing the rules in ways that enhance stability and bring about a reciprocal outcome. Thus there is a "neopatrimonial logic" present in African politics that tends to constrain the development of liberal-democratic forms of governance.

The second lesson is that pushing institutional reforms in a tutelary fashion limits our understanding of the concept and how it may apply to African political realities. In the liberal-democratic approach, institutions are independent of human agency. Hence, people live under rules and, for example, "face the law." Institutions as rules are scripts or schemas that human actors must learn to adopt in order to avoid sanctions. They are structural constraints on action, temporal pathways of regularity, exogenous mechanisms of socialization, or ingrained patterns of cognition (Berk \& Galvan 2009). What we witness in Africa, however, is institutions that are the product of human agency. They are invented and reinvented in social and political processes in which local actors seek an imprint on what rules are applied.

This analysis does not rule out the eventual institutionalization of a more sustainable and stable form of democratic governance in Africa, but it does claim that the logic that holds democratic institutions in place is still only vaguely present. Democracy is not yet the only game in town. Nor is it the mode of governance that convincingly produces the best development results. Comparativists, therefore, have strong reasons to look beyond the liberal-democratic policy paradigm and emphasize the need for a fresh analysis of both institutions and power, as these affect politics in ways that are still to be explored. 


\section{References}

Barry, Brian 1995. Justice as Impartiality. Oxford: Clarendon Press.

Berk, Gerald, and Dennis Galvan. 2009. "How People Experience and Change Institutions: A Field Guide to Creative Syncretism." Theory and Society 38 (6): 543-80.

Bratton, Michael. 2010. "Anchoring the 'D' Word in Africa." Afrobarometer Working Paper No 122. Johannesburg: Afrobarometer.

Bratton, Michael, and Carolyn Logan. 2006. "Voters But Not Yet Citizens: The Weak Demand for Vertical Accountability in Africa's Unclaimed Democracies." Afrobarometer Working Paper No 63. Johannesburg: Afrobarometer.

Collier, David, and Ruth Berins Collier. 1991. Shaping the Political Arena: Critical Junctures, the Labor Movement, and Regime Dynamics in Latin America. Princeton, N.J.: Princeton University Press.

The Economist. 2012. "African Democracy: A Glass Half Full.” March 31.

Erdmann, Gero, and Ulf Engel. 2007. "Neopatrimonialism Reconsidered: Critical Review and Elaboration of an Elusive Concept." Commonwealth and Comparative Politics 45 (1): 95-119.

Freedom House. 2015. Freedom in the World. Washington, D.C.: Freedom House.

Gray, Helen, and Lindsey Whitfield. 2014. "Reframing African Political Economy: Clientelism, Rents and Accumulation as Drivers of Capitalist Transformation." Paper presented at the 57th Annual Meeting of the African Studies Association, Indianapolis, November 20-23.

Henderson, Errol. 2015. African Realism? International Relations Theory and Africa's Wars in the Postcolonial Era. New York: Rowman \& Littlefield.

Huntington, Samuel P. 1991. The Third Wave of Democratization. Norman: University of Oklahoma Press.

Hydén, Göran. 1980 Beyond Ujamaa in Tanzania: Underdevelopment and an Uncaptured Peasantry. Berkeley: University of California Press.

International Commission on Intervention and State Sovereignty. 2001. The Responsibility to Protect: Research, Bibliography and Background. Ottawa: International Development Research Centre.

Khan, Mushtaq. 2010. "Political Settlements and the Governance of GrowthEnhancing Institutions." Research Paper Series on Governance for Growth. School of Oriental and African Studies, University of London.

Lipset, Seymour Martin, and Stein Rokkan, eds. 1967. Party Systems and Voter Alignments: Cross-National Perspectives. New York: Free Press.

Medard, Jean-Francois. 1982. "The Underdeveloped State in Tropical Africa: Political Clientelism or Neopatrimonialism?” In Private Patronage and Public Power, edited by Christopher Clapham, 162-91. London: Pinter.

Mkandawire, Thandika. 2013. "Neopatrimonialism and the Political Economy of Economic Performance in Africa: Critical Reflections." Stockholm: Institute for Future Studies.

O’Donnell, Guillermo. 1994. "Delegative Democracy." Journal of Democracy 5 (1): $55-69$.

Pitcher, Anne, Mary Moran, and Michael Johnston. 2009. "Rethinking Patrimonialism and Neopatrimonialism in Africa." African Studies Review 52 (1): $125-56$.

Reyntjens, Filip. 2013. Political Governance in Post-Genocide Rwanda. New York: Cambridge University Press. 
Therkildsen, Ole. 2005. "Understanding Public Management through NeoPatrimonialism: A Paradigm for All African Seasons?” In The African Exception, edited by Ulf Engel and Gorm Rye Olsen, 35-52. Aldershot, U.K.: Ashgate.

Transparency International. 2015. Global Corruption Report. Berlin: Transparency International.

Young, Crawford. 1994. The African Colonial State in Comparative Perspective. New Haven: Yale University Press. 